\title{
Evaluation of the ecological risk caused by the mobility of radioactive elements and potentially toxic elements during the recultivation of the uranium mining deposit No.1 in Mecsek
}

\author{
Lamlile KHUMALO - György HELTAI - Márk HORVÁTH \\ Szent István University, Gödöllő, Páter K. str. 1. H-2100 Hungary; E-mail: lamlilekhumalo@gmail.com
}

Keywords: Radionuclides, potentially toxic elements, uranium, environment

\section{Introduction}

Mecsek uranium mining and processing had been part of Hungary since 1958 (International Atomic Energy Agency, 2011). This was the only producer of uranium in Hungary (OECD, 2005). The most important information about the Mecsek site is that the mine is located very close to the drinking water catchment area therefore a very important task is the protection of the groundwater quality (International Atomic Energy Agency, 2011).

There is a variety of risks, which arise from mining and milling sites and from any remediation activities. Some of these risks may be damage to the environment and occupational human health risks (OECD Nuclear Energy Agency and the International Atomic Energy Agency, 2002). Mineral mining has the potential to redistribute the minerals in the adjoining area and if adequate safety measures are not implemented, and may enhance natural radioactivity (Sahoo, et al., 2010). According to National Research Council of the National Academies (2012).

\section{Materials and methods}

Soil and vegetation samples were collected from four sampling points (Rn-M11, Rn-M12, Rn-M13 and radioactive point) in Mecsek uranium mine deposit No.1 in Pécs. Each soil sample was taken from different layers $0-25 \mathrm{~cm}, 25-50 \mathrm{~cm}, 50-75 \mathrm{~cm}$ and $75-100 \mathrm{~cm}$. Radioactive soil was sampled from the top layer.

Radon $\left({ }^{222} \mathrm{Rn}\right)$ was measured for soil samples and sample preparations for sequential extraction process for soil and vegetation samples were conducted. Radon measurements were conducted for each soil samples for 24 hours using alpha spectroscopy before sample preparation stage.

The load of potentially toxic elements (PTEs) in soil/water/sediment system is responsible for acute ecotoxicity which is determined by actual speciation of PTEs (Heltai, 2018) using sequential extraction procedure. For Sequential extraction procedures, vegetation samples were air dried, approximately $20 \mathrm{~g}$ of each sample was ashed at $150^{\circ} \mathrm{C}$ from 0 hour and incresed gradually every hour by $25^{\circ} \mathrm{C}$ until it reached $450^{\circ} \mathrm{C}$ and kept stable for 10 hours. Approximately $25 \mathrm{~g}$ of each soil sample was dried at $105^{\circ} \mathrm{C}$ for 72 hours, cooled, grinded and sieved using a $2 \mathrm{~mm}$ pore sieve. 


\section{Results and discussion}

Table: Soil sample preparation results

\begin{tabular}{|c|c|c|c|c|c|c|c|c|c|c|}
\hline 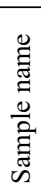 & $\begin{array}{l}\text { Sample } \\
\text { layer } \\
(\mathrm{cm})\end{array}$ & $\begin{array}{l}\text { Dry } \\
\text { mass \% }\end{array}$ & 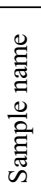 & $\begin{array}{l}\text { Sample } \\
\text { layer } \\
(\mathrm{cm})\end{array}$ & $\begin{array}{l}\text { Dry } \\
\text { mass \% }\end{array}$ & 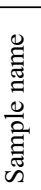 & $\begin{array}{l}\text { Sample } \\
\text { layer } \\
(\mathrm{cm})\end{array}$ & $\begin{array}{l}\text { Dry } \\
\text { mass \% }\end{array}$ & 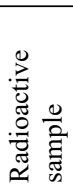 & $\begin{array}{l}\text { Dry } \\
\text { mass \% }\end{array}$ \\
\hline \multirow{4}{*}{ 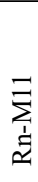 } & $0-25$ & 90.76 & \multirow{4}{*}{ 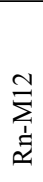 } & $0-25$ & 90.53 & \multirow{4}{*}{$\sum_{\substack{1 \\
\Sigma}}^{\infty}$} & $0-25$ & 82.93 & \multirow{4}{*}{ 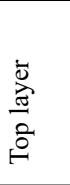 } & \multirow[t]{4}{*}{35.36} \\
\hline & $25-50$ & 92.56 & & $25-50$ & 91.01 & & $25-50$ & 85.66 & & \\
\hline & $50-75$ & 87.41 & & $50-75$ & 91.81 & & $50-75$ & 85.85 & & \\
\hline & $75-100$ & $\begin{array}{l}\text { Hard } \\
\text { rock }\end{array}$ & & $75-100$ & 91.57 & & $75-100$ & 85.80 & & \\
\hline
\end{tabular}

Sample preparation for both soil and vegetation sample have been completed, including drying and ashing for elemental analysis and the BCR extraction. The analysis of samples is in progress.

\section{Conclusions}

The study is still in progress. The soil samples were digested and the solutions from digested soil samples and ashed vegetation samples were used for speciation analysis through sequential extraction procedure by using inductively coupled plasma optical emission spectrometry (ICP-OES) for the determination of the fraction distribution of metals in soils. Different radionuclides for both soil and vegetation samples were detected by gamma spectroscopy.

\section{Acknowledgement}

This research is supported by Stipendium Hungaricum Reg. No.: 238700 and South African Department of Higher Education and Training

\section{References}

Heltai, G., Győri, Z., Fekete, I., Halász, G., Kovács, K., Takács, A., ... Horváth, M. (2018). Longterm study of transformation of potentially toxic element pollution in soil/water/sediment system by means of fractionation with sequential extraction procedures. Microchemical Journal, 136, 85-93. https://doi.org/10.1016/j. microc.2017.01.026.

International Atomic Energy Agency (2011): The Uranium Mining Remediation Exchange Group (UMREG). Vienna: IAEA Publishing.

OECD Nuclear Energy Agency and the International Atomic Energy Agency (2002): Environmental remediation of Uranium roduction Facilities. OECD Publication, Paris, Franc.

OECD (2005): Uranium (2005): Resources, Production and Demand. OECD Publications, Paris, France.

National Research Council of The National Academies (2012): Uranium Mining in Virginia. The National Academies Press., Washington, D. C.

Sahoo, S. K., Mohapatra, S., Sethy, N. K., Patra, A. C., Shukla, A. K., Kumar, A. V., et al. (2010, March 19): Natural radioactivity in roadside soil along Jamshedpur-Musabani Road: A mineralised and mining region, Jharkhand and associated ris. Radiation Protection Dosimetry. 140: 3. 281-286. 